\title{
The Effect of Listening to the Murottal Qur'an Against Schizophrenia in Inpatients at the Mental Hospital of Southeast Sulawesi Province
}

\author{
Rahmat Ramadan ${ }^{1}$, Junuda RA ${ }^{2}$, Adius Kusnan ${ }^{3}$, Tien ${ }^{4}$, Sunandar Ihsan ${ }^{5}$, Amiruddin Eso ${ }^{6}$ \\ \{rahmatramadan1701@gmail.com ${ }^{1}$,junudaraf2011@gmail.com², adius_kusnan@yahoo.com ${ }^{3}$, \\ tiensyamsuddin@yahoo.com ${ }^{4}$, sunandarihsan@uho.ac.id ${ }^{5}$, amir_fk_unhalu@yahoo.co.id $\left.{ }^{6}\right\}$ \\ ${ }^{123456}$ Faculty of Medicine Halu Oleo University, Kendari, Indonesia
}

\begin{abstract}
Schizophrenia is a complex mental disorder with combination symptoms, basically caused by biochemical imbalances of neurotransmitters in the brain. Single antipsychotic therapy cannot effectively improve the symptoms of schizophrenia. So, additional therapy is needed for better results. This study generally aims to analyze the effect of listening to the recitation of the Holy Qur'an against schizophrenia in inpatients at the Mental Hospital of Southeast Sulawesi Province. This research is quasi-experimental research with a pretestposttest with a group control design. The study population was all schizophrenic patients who were hospitalized in the Mental Hospital of Southeast Sulawesi Province. The sample of this study were 34 peoples. Data were collected using the Positive and Negative Syndrome Scale (PANSS) observation sheet. Data analysis used the Mann-Whitney test to compare PANSS scores average of the treatment group and the control group. The result showed that there were significant differences in the average of the PANSS scores between the treatment group and the control group with $p$-value $=0.005$. It is concluded that listening to the Qur'an recitation had decreased PANSS scores bigger than the group that is not listening to a Qur'an recitation.
\end{abstract}

Keywords-Mental hospital of southeast sulawesi, listening murottal qur'an, PANSS, schizophrenia

\section{Introduction}

Schizophrenia is a complex mental disorder with heterogeneous and diverse variations of positive, negative, and cognitive [1]. Basically, schizophrenia is caused by biochemical imbalances of neurotransmitters in the brain, especially in the dopaminergic pathway, which manifests in misperceptions about reality [2], [3]. In general, the prevalence of schizophrenia in the world passes $1 \%$. However, a systematic update by Saha et al., Based on 188 studies from 46 countries discussing the risk of schizophrenia reaching 4 out of 1000 population or $0.4 \%$ [4]. In Indonesia, based on 2018 Riskesdas Results the prevalence of schizophrenia increased from $1.7 \%$ in 2013 to 7\% in 2018. While in the Southeast Sulawesi report from Health Research and 
Development Agency as of 2018 the prevalence of schizophrenia was more than 5\% [5]. How to deal with other physical and mental disorders, such as anxiety and depression. Besides, suicide is one of the leading causes of death in people with schizophrenia who support the severity of depression experienced [6]. Regarding the goals of therapy, Schizophrenia discusses management, prevents a recurrence, and fosters adaptive function to be able to re-assimilate with the community [7]. Although antipsychotic therapy is the main therapy for schizophrenia, research has found facts about psychosocial interventions, including psychotherapy that can complement clinical improvement [8]. Al-Qur'an Therapy is also developed as an additional therapeutic modality that shows the existence of Al-Qur'an therapy supplements to peace that can reduce stress, anxiety, and depression [9].

Meanwhile, in the Qur'an surah Al-Israa '[17] verse 82 of Allah Subhanahu Wata' Ala said in His Kitab, "And we sent down from the Qur'an about which leads to the antidote and mercy for the peoples who believe and the Qur'an adds to the advantages of wrongdoers in addition to losses". This verse explains that the Qur'an is a healer and a blessing for those who believe (Abdullah, 1994). In other studies the holy Qur'an improve mental health [10], and listening Qur'an can reduce the level of anxiety patient [11]. Schizophrenia is a mental disorder like anxiety with dopaminergic pathways [2] and hippocampal-amygdala pathways [12].

Thus the background of this study, which is intended to determine the effect of listening AlQur'an recitation therapy to the patient of schizophrenia at the Mental Hospital of Southeast Sulawesi Province.

\section{Method}

This study was included in a quasi-experimental research design with a pretest-posttest with control group design. This research took place in July-August 2019 at the Mental Hospital of Southeast Sulawesi Province. The population in this study were all schizophrenic patients who were hospitalized in the Mental Hospital of Southeast Sulawesi Province. The samples in this study were 34 samples which were divided into two groups: 17 samples in the control group and 17 other samples in the treatment group. The instrument used in this study was the Observation Sheet Positive and Negative Syndrome Scale (PANSS). The total PANSS score indicated the severity of the symptoms of schizophrenia, the higher of the PANSS score means the severity of the symptoms of schizophrenia was also getting heavier. The treatment given was the sample of the study performed Qur'an recitation (murrotal) 1 time/day (Surah AlIkhlas, Al-Falaq, and An-Naas with a duration of 2 minutes/day) which giving for 2 weeks (or 14 times giving).

\section{Result And Discussion}

Based on the data collection, 34 people were able to become research samples divided into two groups. The treatment group received murottal Quran therapy and standard therapy for schizophrenia patients, while the control group did not get murottal Quran therapy but received standard therapy for schizophrenia patients. The results showed that the difference between the PANSS scores of the two groups has a significant difference with $\mathrm{p}$-value $=0.005(\mathrm{p}<0.05)$. Besides that, it can be seen the difference in the mean of each group, in the control group it has a smaller mean of pre and post which is 3.75 compared to the treatment group that has a 
difference of 11.33. This showed a decrease in the PANSS score of the treatment group is greater than the control group.

Based on this study it can be seen that there was a decrease in the PANSS score of the control group which previously on the pretest score was 46.47 became to 42.06 on the posttest score. A similar thing happened in the treatment group, namely the decrease in PANSS score of the previous treatment group on the pretest score by 46.18 became to 35.47 in the posttest score in Table 1.

Table 1 PANSS scores measurement results

\begin{tabular}{ccc}
\hline & n & Mean \pm s.d \\
\hline Pretest Control Group & 17 & $46.47 \pm 10.30$ \\
Posttest Control Group & 17 & $42.06 \pm 8.14$ \\
Pretest Treatment Group & 17 & $46.18 \pm 11.64$ \\
Posttest Treatment Group & 17 & $35.47 \pm 5.77$ \\
\hline
\end{tabular}

As explained previously, both in the treatment group that was played murottal Qur'an and the control group that was not played murottal Qur'an there was still a decrease in PANSS scores. This means, even if only getting antipsychotic therapy without murottal Qur'an therapy, it still results in a decrease in the symptoms of schizophrenia. But with the provision of additional therapy in the form of murottal Qur'an improvement of symptoms will be even greater.

Then to see the difference between the control group that was not played by the murottal Qur'an and the treatment group that was played by the Qur'an murottal, a Mann-Whitney test was performed to compare the difference in PANSS score between the two groups for which data were not normally distributed (Look Table 2). However, before a statistical test is performed, a matching sample is first performed to uniform the combination of therapies obtained for each sample in the control group and the treatment group. So it was found, 12 samples in each group with 4 types of combination therapy.

Research on the effects of Al-Qur'an therapy was also carried out by [13] about the additional voice therapy of Al-Qur'an for depressed patients at RSUP Dr. Sardjito Yogyakarta. From the results of his research, it was shown that standard drug therapy and additionally recitation of the Qur'an both can reduce BDI scores (Beck Depression Inventory), besides that there were significant differences in the value of the difference between pre and post BDI scores between patients receiving drug therapy (control group) with patients who received voice reading Al-Qur'an (treatment group) with $\mathrm{p}$-value $=0.005(\mathrm{p}<0.05)$, as well as the difference in the treatment group by 14.67 which is greater than the control group that is 3.89 . This study suggests that the recitation of al Qur'an can be used concomitantly with standard drug therapy.

Table 2 Test results of the difference in the mean between the two groups

\begin{tabular}{ccccc}
\hline & n & Median (min-max) & Mean \pm s.d & $\boldsymbol{P}$ \\
\hline Average Control Group & 12 & $3.50(-6-17)$ & $3.75 \pm 5.46$ & 0.005 \\
Average Treatment Group & 12 & $7.50(2-30)$ & $11.33 \pm 9.21$ &
\end{tabular}

The treatment goal of schizophrenia is to reduce symptomatology and relapse and improve social outcomes. Psychosocial and other treatments are needed concomitantly if other symptoms are present [14]. Antipsychotic therapy can only help in correcting chemical imbalances, so additional modalities of adjunct therapy in the form of non-pharmacological therapy are needed. This is also in line with research conducted by [7] that the management of 
pharmacological and non-pharmacological therapies must be used together to obtain better results. There is a benefit with spiritual and religious issues for psychotherapy especially for schizophrenia treatment [15]. One of the religious issues is the sound of the Holy Qur'an because it is effective for those not respond with psychological treatment but effectiveness related to willingness positively of the patient [16]. In Muslim tradition, Qur'an is a verbatim word of God revealed to the prophet Muhammad saw and it's becoming a sacred book that used a daily prayer for entire life [17]. Quranic language is distinct from others and has its miracle with a unique tone and style [18].

From the above explanation, it can be concluded that Qur'an recitation (murottal) therapy influences reducing the severity of schizophrenia. Although giving a single antipsychotic can reduce PANSS scores, with the presence of murottal Qur'an therapy as an additional therapy that runs simultaneously the PANSS score reduction will be much greater and stable. The effect of qur'anic recitation pass thorough limbic system pathways and reduce stress hormone cortisol and induced the relaxation that is indicated by an increase alpha electroencephalograms EEG waves [19].

\section{Conclusion}

There was a significant difference in the PANSS score between treatment group with the Qur'anic recitation, schizophrenia patients who were heard murottal Qur'an, compared to control group who did not listen of Qur'an recitation in inpatients at the Mental Hospital of Southeast Sulawesi Province with $\mathrm{p}$-value $=0.005(\mathrm{p}<0.05)$. Listening to Quranic recitation can improve mental health with increased spiritual consciousness bring a positive effect on schizophrenia patients.

\section{Acknowledgment}

The authors are thankful to the RSU Jiwa Provinsi Sulawesi Tenggara for support our study.

\section{Refferences}

[1] R. S. Kahn et al., "Schizophrenia," Nat. Rev. Dis. Prim. Vol., 2015.

[2] O. D. Howes, R. McCutcheon, M. J. Owen, and R. M. Murray, "The Role of Genes, Stress, and Dopamine in the Development of Schizophrenia," Biol. Psychiatry, vol. 81, no. 1, pp. 9-20, 2017.

[3] I. Uhl et al., "Central serotonergic function in patients with predominantly negative symptoms of schizophrenia," Schizophr. Res., vol. 193, pp. 443-444, 2013.

[4] G. Ayano, "Schizophrenia: A Concise Overview of Etiology, Epidemiology Diagnosis, and Management: Review of literatures," SOJ Psychol., vol. 3, no. 2, pp. 1-8, 2016.

[5] RISKESDAS, "Hasil Utama Riset Kesehatan Dasar 2018," 2018.

[6] C. Galletly et al., "Royal Australian and New Zealand College of Psychiatrists clinical practice guidelines for the management of schizophrenia and related disorders," Aust. N. Z. J. Psychiatry, vol. 50, no. 5, pp. 1-117, 2016.

[7] B. Z. Fatani, R. A. Aldawod, and F. A. Alhawaj, "Schizophrenia : Etiology, Pathophysiology and Management: A Review," Egypt. J. Hosp. Med., 2017. 
[8] F. B. Dickerson and A. F. Lehman, "Evidence-Based Psychotherapy for Schizophrenia: 2011 Update," J. Nerv. Ment. Dis., vol. 199, no. 8, pp. 520-526, 2011.

[9] B. Jabbari, M. Mirghafourvand, F. Sehhatie, and S. Mohammad-Alizadeh-Charandabi, "The Effect of Holly Quran Voice With and Without Translation on Stress, Anxiety and Depression During Pregnancy: A Randomized Controlled Trial,” J. Relig. Health, vol. 59, pp. 544-554, 2017.

[10] M. Mahjoob, J. Nejati, A. Hosseini, and N. M. Bakhshani, "The Effect of Holy Quran Voice on Mental Health," J. Relig. Health, vol. 55, pp. 38-42, 2014.

[11] A. Ghiasi and A. Keramat, "The Effect of Listening to Holy Quran Recitation on Anxiety: A Systematic Review," Iran. J. Nurs. Midwifery Res., vol. 23, no. 6, pp. 411-420, 2018.

[12] K. J. Ressler and C. B. Nemeroff, "Role of serotonergic and noradrenergic systems in the pathophysiology of depression and anxiety disorders," Depression and Anxiety. 2000.

[13] S. IHSAN, "EFEKTIVITAS TERAPI TAMBAHAN SUARA BACAAN AL QUR'AN TERHADAP PASIEN DEPRESI DI RSUP. DR. SARDJITO YOGYAKARTA," Universitas Gadjah Mada, 2013.

[14] Marie A. Chisholm-Burns, Pharmacotherapy Principles \& Practice, Fourth Edi., vol. Fourth Edi. New York: McGraw-Hill Companies, Inc., 2016.

[15] L. Mizock, U. C. Millner, and Z. Russinova, "Spiritual and Religious Issues in Psychotherapy with Schizophrenia: Cultural Implications and Implementation," Religions, vol. 3, pp. 82-98, 2012.

[16] A. A. G. Saged et al., "Impact of Quran in Treatment of the Psychological Disorder and Spiritual Illness," J. Relig. Health, 2018.

[17] Z. I. Ali, "Islam: Religion, History, and Civilization (review)," Philos. East West, vol. 56, no. 3, pp. 495-497, 2006.

[18] Y. M. Noor and M. S. Sahrir, "Hermeneutics and the Qur'anic Texts in the Intellectual Linguistic Context," in The 3rd International Conference of Arabic Language and Literature, 2011.

[19] N. A. Zulkurnaini, R. S. S. A. Kadir, Z. H. Murat, and R. M. Isa, "The comparison between listening to Al-Quran and listening to classical music on the brainwave signal for the alpha band," in Proceedings - 3rd International Conference on Intelligent Systems Modelling and Simulation, 2012. 